\title{
EFEKTIVITAS EXTRA VIRGIN COCONUT OIL DAN OLIVE OIL TERHADAP FUNGSI MEMORI DAN BELAJAR MENCIT
}

\author{
THE EFFECT OF EXTRA VIRGIN COCONUT OIL AND OLIVE OIL \\ TOWARD MEMORY AND STUDY FUNCTION IN MICE \\ Gorga Menak Sihombing, * Rizna Tyrani Rumanti, ** Decky Gunawan***
}

\section{ABSTRACT}

Introduction: Dementia is a neurodegenerative syndrome caused by chronic progressive abnormality and multiple malfunctions of the noble functions especially in memory and learning. Medium chain triglycerides (MCT) and polyphenol in extra virgin coconut oil (EVCO) and extra virgin olive oil (EVOO) can increase cognitive function.

Aim: To discover the effect of extra virgin coconut oil (EVCO), extra virgin olive oil (EVOO) on increasing memory and learning ability of mice that are induced by aluminium chloride $\left(\mathrm{AlCl}_{3}\right)$.

Methods: A true experimental study was conducted using a completely randomized and comparative design. Experimental subjects were 24 mice, divided into 4 groups: $\mathrm{K} 1$ (negative control, aquades), $\mathrm{K2}$ ( $\mathrm{AlCl}_{3}+$ aquades), $\mathrm{K3}$ $\left(\mathrm{AlCl}_{3}+\mathrm{EVCO} 30 \mathrm{~mL} / \mathrm{kg} /\right.$ day $)$, and $\mathrm{K} 4\left(\mathrm{AlCl}_{3}+\mathrm{EVOO} 30 \mathrm{~mL} / \mathrm{kg} /\right.$ day $)$. Aluminium chloride was given for 15 days, then continued by EVCO and EVOO for 15 days. The dependent variable was recognition index (RI) with object recognition test post treatment. Data was analyzed using ANOVA, continued by LSD test with $\alpha=0.05$.

Results: Recognition index between K3 and both K1 and K2 showed a highly significant difference, and RI between $K 4$ and both $K 1$ and $K 2$ also showed a highly significant difference. $K 4$ was better in increasing RI compared with K3 with significant difference.

Discussion: Extra virgin olive oil and EVOO improved the learning function and memory of mice induced by AlCl3. Extra virgin olive oil worked better than EVCO, because EVOO contains polyphenols that can work as neuroinflammation, neurotoxicity and neuronal dysfunction inhibitors, while EVCO contains MCT as the main energy source when nerve damage occurs.

Keywords: Dementia, extra virgin coconut oil (oleum cocos), extra virgin olive oil (oleum olivae), learning, memory

\section{ABSTRAK}

Pendahuluan: Demensia adalah sindrom neurodegeneratif yang timbul karena adanya kelainan yang bersifat kronis dan progresif disertai dengan gangguan fungsi luhur multipel terutama pada memori dan belajar. Medium chain triglycerides (MCT) dan polifenol pada extra virgin coconut oil (EVCO) dan extra virgin olive oil (EVOO) dapat meningkatkan fungsi kognitif.

Tujuan: Untuk mengetahui efek pemberian EVCO, EVOO, serta membandingkan keduanya dalam meningkatkan fungsi memori dan belajar mencit yang diinduksi aluminium klorida $\left(\mathrm{AlCl}_{3}\right)$.

Metode: Penelitian dengan desain studi eksperimental sungguhan menggunakan rancangan acak lengkap dan bersifat komparatif, dengan subjek penelitian 24 ekor mencit Swiss Webster yang dibagi menjadi 4 kelompok: K1 (kontrol negatif, akuades), $\mathrm{K} 2\left(\mathrm{AlCl}_{3}+\right.$ akuades$), \mathrm{K} 3\left(\mathrm{AlCl}_{3}+\mathrm{EVCO} 30 \mathrm{~mL} / \mathrm{kgBB} / \mathrm{hari}\right)$, dan $\mathrm{K} 4\left(\mathrm{AlCl}_{3}+\mathrm{EVOO} 30 \mathrm{~mL} / \mathrm{kgBB} / \mathrm{hari}\right)$. Aluminium klorida diberikan selama 15 hari, dilanjutkan dengan pemberian EVCO dan EVOO selama 15 hari. Variabel respons adalah indeks rekognisi (IR), dengan object recognition test setelah perlakuan. Analisis data dengan ANOVA dilanjutkan uji LSD dengan $\alpha=0,05$.

Hasil: Perbandingan IR K3 dengan K1 dan K2 memiliki perbedaan yang sangat bermakna, sedangkan K4 dengan K1 dan K2 memiliki perbedaan yang sangat bermakna. Kelompok 4 lebih baik dalam meningkatkan IR dibandingkan K3 dengan perbedaan bermakna.

Diskusi: Extra virgin coconut oil dan EVOO meningkatkan fungsi belajar dan memori mencit yang diinduksi $\mathrm{AlCl}_{3}$ Extra virgin olive oil lebih baik dibandingkan EVOO, karena EVOO mengandung polifenol yang dapat bekerja sebagai penghambat neuroinflamasi, neurotoksisitas, dan disfungsi neuron, sedangkan EVCO mengandung MCT sebagai kandungan utama yang berperan sebagai sumber energi utama bila terjadi kerusakan saraf.

Kata kunci: Belajar, demensia, extra virgin coconut oil (oleum cocos), extra virgin olive oil (oleum olivae), memori

*FK Universitas Kristen Maranatha, Bandung; **Bagian Anatomi FK Universitas Kristen Maranatha, Bandung; Bagian Fisiologi FK Universitas Kristen Maranatha, Bandung. Korespondensi: sihombing.gorga@gmail.com. 


\section{PENDAHULUAN}

Kognisi berarti proses berpikir pada otak, dengan menggunakan input sensorik yang menuju otak ditambah informasi yang telah disimpan sebagai memori. ${ }^{1}$ Fungsi kognitif meliputi persepsi, atensi, memori, orientasi, representasi pengetahuan, pemecahan masalah, bahasa, dan belajar. ${ }^{2}$ Fungsi kognitif yang baik sangat diperlukan dalam kehidupan sehari-hari seseorang agar dapat produktif. Belajar adalah mendapatkan pengetahuan atau keterampilan sebagai akibat dari pengalaman, arahan atau keduanya. Memori adalah penyimpanan pengetahuan yang diperoleh agar dapat diingat kembali. Belajar dan memori membentuk dasar cara individu beradaptasi dengan lingkungannya. ${ }^{3}$ Memori dan proses belajar dapat mengalami gangguan antara lain diakibatkan oleh demensia. ${ }^{4-6}$

Definisi demensia menurut World Health Organization (WHO) adalah sindrom neurodegeneratif yang timbul karena adanya kelainan yang bersifat kronis dan progresif disertai dengan gangguan fungsi luhur multipel seperti kalkulasi, kapasitas belajar, bahasa, dan mengambil keputusan. Gangguan fungsi kognitif biasanya disertai dengan perburukan kontrol emosi, perilaku, dan motivasi. Sampai saat ini belum ada pengobatan yang adekuat untuk mengatasi demensia. Upaya pencegahan masih menjadi langkah terbaik untuk mengatasi demensia. ${ }^{7}$

Prevalensi demensia di dunia menurut data WHO tahun 2016 yaitu 47,5 juta orang mengalami demensia, dengan setengahnya tinggal di negara berpendapatan rendah dan sedang. Setiap tahun ada 7,7 juta kasus baru. Diperkirakan pada usia lebih dari 60 tahun terdapat 5-8 dari 100 orang terkena demensia. Diperkirakan pada tahun 2030 penderita demensia mencapai 75,6 juta orang dan akan meningkat tiga kalinya pada tahun 2050 menjadi 135,5 juta orang. ${ }^{7}$

Aluminium adalah logam yang paling berlimpah di bumi. Logam ini dapat masuk ke dalam tubuh antara lain melalui makanan, minuman, deodoran, dan obat-obatan. Di dalam jaringan otak, aluminium dapat terakumulasi di hipokampus dan korteks frontal dan diduga berperan dalam patogenesis kelainan neurodegenerasi. Neurodegenerasi yang terjadi dihubungkan dengan peningkatan ekspresi amyloid precursor protein (APP), deposit amyloid $\beta$ (A $\beta)$, gangguan proyeksi kolinergik, kematian apoptosis neuronal, dan phosphorylated tau overexpression. ${ }^{8}$ Berbagai suplemen sudah banyak diuji dapat menjaga dan meningkatkan fungsi memori dan belajar, diantaranya coconut oil dan olive oil. Penelitian mengenai coconut oil menyebutkan dapat meningkatkan fungsi kognitif. ${ }^{9}$ Penelitian lain menunjukan bahwa olive oil memiliki efek menguntungkan dalam proses belajar dan memori. ${ }^{10}$

Olive oil (oleum olivae) atau minyak zaitun sering disebut minyak sehat karena tinggi akan lemak tidak jenuh. Olive oil sejak dulu sering digunakan untuk kecantikan dan kesehatan kulit. Coconut oil (oleum cocos) atau minyak kelapa juga banyak digunakan di negara-negara tropis. Tetapi coconut oil memiliki kandungan lemak jenuh yang tinggi bila dibandingkan dengan olive oil sehingga dapat membahayakan kesehatan jantung. Jenis minyak dengan kualitas terbaik adalah extra virgin. Extra virgin oil adalah minyak yang diproses tanpa pemanasan dan tambahan bahan kimia yang memiliki kandungan nutrisi yang paling tinggi.

\section{TUJUAN}

Untuk meneliti perbandingan efektivitas extra virgin coconut oil dan extra virgin olive oil terhadap fungsi memori dan belajar pada mencit Swiss Webster yang diinduksi aluminium klorida.

\section{METODE}

Penelitian dengan desain studi eksperimental sungguhan dengan menggunakan Rancangan Acak Lengkap (RAL) dan bersifat komparatif. Data yang diukur adalah proses belajar dan memori mencit yang dinilai berdasarkan Indeks Rekognisi (IR). ${ }^{11}$ Analisis data menggunakan uji t berpasangan untuk menganalisis penurunan fungsi kognitif mencit sebelum dan setelah diberi aluminium klorida (AlCl3). Selanjutnya data dianalisis dengan uji ANOVA satu arah dan dilanjutkan dengan uji Least Significant Difference (LSD). Alat yang digunakan pada penelitian ini adalah sonde oral, sarung tangan, spuit $3 \mathrm{~mL}$, stopwatch, neraca analisis digital, tabung 
reaksi $250 \mathrm{~mL}$, pakan mencit, sekam, kandang mencit, kotak transparan $(33 \times 33 \times 20 \mathrm{~cm})$, objek novel dan objek familiar, kamera, alkohol 70\%.

Bahan penelitian yang dipakai yaitu extra virgin coconut oil (oleum cocos) dengan merk " $\mathrm{X}$ ", extra virgin olive oil (oleum olivae) dengan merk "Y", akuades, $\mathrm{AlCl} 3$ dengan merk "M". Subjek penelitian yang digunakan adalah 24 ekor mencit betina galur Swiss Webster usia pubertas (50-60 hari) dengan berat badan rata-rata $20-25 \mathrm{~g}$. Selama penelitian, mencit dipelihara di dalam kandang yang berisi sekam padi, diberi makan pelet dan minum air suling serta diadaptasikan selama satu minggu. Coconut oil dan olive oil digunakan pada penelitian ini diperoleh dari salah satu supermarket di Kota Bandung.

Dua puluh empat mencit Swiss Webster jantan dibagi secara acak menjadi empat kelompok: (1) kelompok 1: akuades; (2) kelompok 2: induksi aluminium klorida dilanjutkan dengan akuades (14 hari); (3) kelompok 3: induksi aluminium klorida dilanjutkan dengan extra virgin coconut oil (14 hari); (4) kelompok 4: induksi alumnium klorida dilanjutkan dengan extra virgin olive oil (14 hari).

Selama 7 hari dilakukan adaptasi. Setelah adaptasi dilakukan pretest induksi selama 2 hari. Kemudian setelah dilakukan pretest, kelompok 2, 3, dan 4 diberikan aluminium klorida sebanyak 5mg per oral selama 14 hari. Pada hari ke-24 dilakukan kembali tes novel object recognition (posttest) untuk mengetahui apakah ketiga kelompok tersebut telah mengalami demensia dibandingkan dengan data sebelum pemberian induksi (pretest).

Setelah itu kelompok 2, 3, dan 4 selama 14 hari diberi perlakuan masing-masing secara oral: (1) kelompok 2: akuades (kontrol negatif); (2) kelompok 3: extra virgin coconut oil dengan dosis $0,156 \mathrm{~mL} /$ hari; (3) kelompok 4: extra virgin olive oil dengan dosis $0,156 \mathrm{~mL} /$ hari.

Setelah diberikan perlakuan, keesokan harinya mencit kembali dilakukan tes novel object recognition. Tahap pertama yaitu tahap habituasi dengan cara mencit ditempatkan di kotak, menghadap dinding terdekat dengan peneliti, lalu mencit dibiarkan bereksplorasi selama 5 menit, mencit lalu dikembalikan ke dalam kandang, selanjutnya kotak dibersihkan menggunakan alkohol 70\% untuk meminimalisasi pengaruh bantuan penciuman mencit pada tahap berikutnya.

Setelah tahap habituasi, keesokan harinya mencit masuk tahap kedua yaitu tahap pengenalan, dengan cara 2 objek yang serupa ditempatkan di dalam kotak, $5 \mathrm{~cm}$ dari dinding. Sepasang objek tersebut harus dirandomisasi pada setiap mencit dan kelompok, mencit diletakkan membelakangi kedua benda, dibiarkan bereksplorasi selama 10 menit. Penelitian dihentikan setelah periode 10 menit berakhir, lalu mencit dikembalikan ke dalam kandang, kotak dibersihkan kembali menggunakan alkohol $70 \%$ setelah tahap pengenalan kemudian dikeringkan.

Setelah tahap pengenalan selesai dilanjutkan dengan tahap ketiga yaitu tahap pengujian dengan cara salah satu dari kedua objek familar diganti dengan objek novel. Dipastikan tidak ada jejak bau dari objek novel. Objek ditempatkan pada posisi yang sama, $5 \mathrm{~cm}$ dari dinding. Setiap penempatan objek novel dilakukan secara acak. Waktu eksplorasi mencit pada objek novel diukur, dibandingkan dengan berapa lama waktu eksplorasi mencit pada objek familiar, untuk menghitung indeks rekognisi. ${ }^{11}$

\section{HASIL}

Hasil penelitian ini didapatkan rata-rata indeks rekognisi sebelum diberi induksi $\mathrm{AlCl}_{3}$ sebesar 0,64 pada kelompok 2; 0,62 pada kelompok 3; dan 0,61 pada kelompok 4. Setelah diberi induksi $\mathrm{AlCl}_{3}$ ratarata indeks rekognisi sebesar 0,43 pada kelompok

Tabel 1. Rerata Indeks Rekognisi Sebelum dan Setelah Induksi $\mathrm{AlCl}_{3}(\mathrm{n}=24)$

\begin{tabular}{llcc}
\hline \multirow{2}{*}{ Perlakuan } & \multirow{n}{*}{} & \multicolumn{2}{c}{ Indeks Rekognisi } \\
\cline { 3 - 4 } & & Sebelum Induksi & Setelah Induksi \\
\hline Kelompok 1 & 6 & 0,66 & 0,65 \\
Kelompok 2 & 6 & 0,64 & 0,43 \\
Kelompok 3 & 6 & 0,62 & 0,43 \\
Kelompok 4 & 6 & 0,61 & 0,42 \\
\hline
\end{tabular}

Kelompok 1: Akuades; Kelompok 2: Induksi AlCl3 (14 hari) dilanjutkan dengan akuades (14 hari); Kelompok 3: Induksi AlCl3 (14 hari) dilanjutkan dengan extra virgin coconut oil (14 hari); Kelompok 4: Induksi AlCl3 (14 hari) dilanjutkan dengan extra virgin olive oil (14 hari). $\mathrm{AlCl}_{3}$ : Aluminium chlorida. 
2; 0,43 pada kelompok 3; dan 0,42 pada kelompok 4 (Tabel 1). Hal tersebut menunjukkan penurunan indeks rekognisi setelah diberi $\mathrm{AlCl}_{3}$ pada ketiga kelompok mencit.

Selanjutnya dilakukan uji t berpasangan untuk mengetahui ada tidaknya perbedaan rerata indeks rekognisi mencit antara kelompok sebelum dan setelah diberi induksi $\mathrm{AlCl}_{3}$. Hasil uji t berpasangan pada kelompok 2, 3, dan 4 diperoleh nilai $\mathrm{p}=0,002$; $\mathrm{p}=0,006 ; \quad \mathrm{p}=0,008 \quad(\mathrm{p}<0,05)$ yang menunjukan perbedaan yang sangat signifikan. Hal ini berarti terdapat perbedaan rata-rata yang sangat signifikan antara kelompok sebelum dan setelah diberi induksi $\mathrm{AlCl}_{3}$. Dapat disimpulkan bahwa mencit pada kelompok 2, 3, dan 4 mengalami demensia setelah diinduksi $\mathrm{AlCl}_{3}$.

Setelah dilakukan induksi $\mathrm{AlCl}_{3}$ selama 2 minggu, mencit diberi perlakuan berupa extra virgin coconut oil untuk kelompok 3 dan extra virgin olive oil untuk kelompok 4, sedangkan kelompok 1 dan 2 diberi akuades. Dua minggu kemudian dilakukan pengamatan fungsi belajar dan memori mencit dengan cara menghitung indeks rekognisi. Hasil dapat dilihat pada Gambar 1.

Indeks Rekognisi tertinggi didapatkan pada kelompok 1 (kontrol negatif) yaitu sebesar 0,67; diikuti oleh kelompok 4 (extra virgin olive oil) yaitu sebesar 0,59; dan oleh kelompok 3 (extra virgin coconut oil) sebesar 0,53. Indeks Rekognisi terendah didapatkan pada kelompok 2 (induksi $\mathrm{AlCl}_{3}+$ akuades) yaitu sebesar 0,43 .

Dilakukan uji ANOVA untuk mengetahui ada tidaknya perbedaan rerata indeks rekognisi antar kelompok perlakuan. Hasil uji ANOVA diperoleh hasil sangat signifikan dengan nilai $\mathrm{p}=0,000$ $(p<0,05)$. Hal ini berarti minimal terdapat sepasang kelompok perlakuan dengan indeks rekognisi yang berbeda. Selanjutnya dilakukan uji lanjut LSD untuk mengetahui kelompok perlakuan mana yang mempunyai hasil berbeda signifikan. Hasil uji LSD dapat dilihat pada Tabel 2.

Hasil uji LSD menunjukkan terdapat perbedaan Indeks Rekognisi yang sangat signifikan $(\mathrm{p}=0,000)$ antara kelompok 1, kelompok 3, dan kelompok 4 dengan kelompok 2. Antara kelompok 1 dengan kelompok $3(\mathrm{p}=0,000)$ didapatkan perbedaan yang sangat signifikan dan antara kelompok 1 dengan kelompok $4(\mathrm{p}=0,004)$ didapatkan perbedaan yang sangat signifikan. Perbandingan antara kelompok 3 dengan kelompok 4 didapatkan pula hasil yang signifikan $(\mathrm{p}=0,015)$.

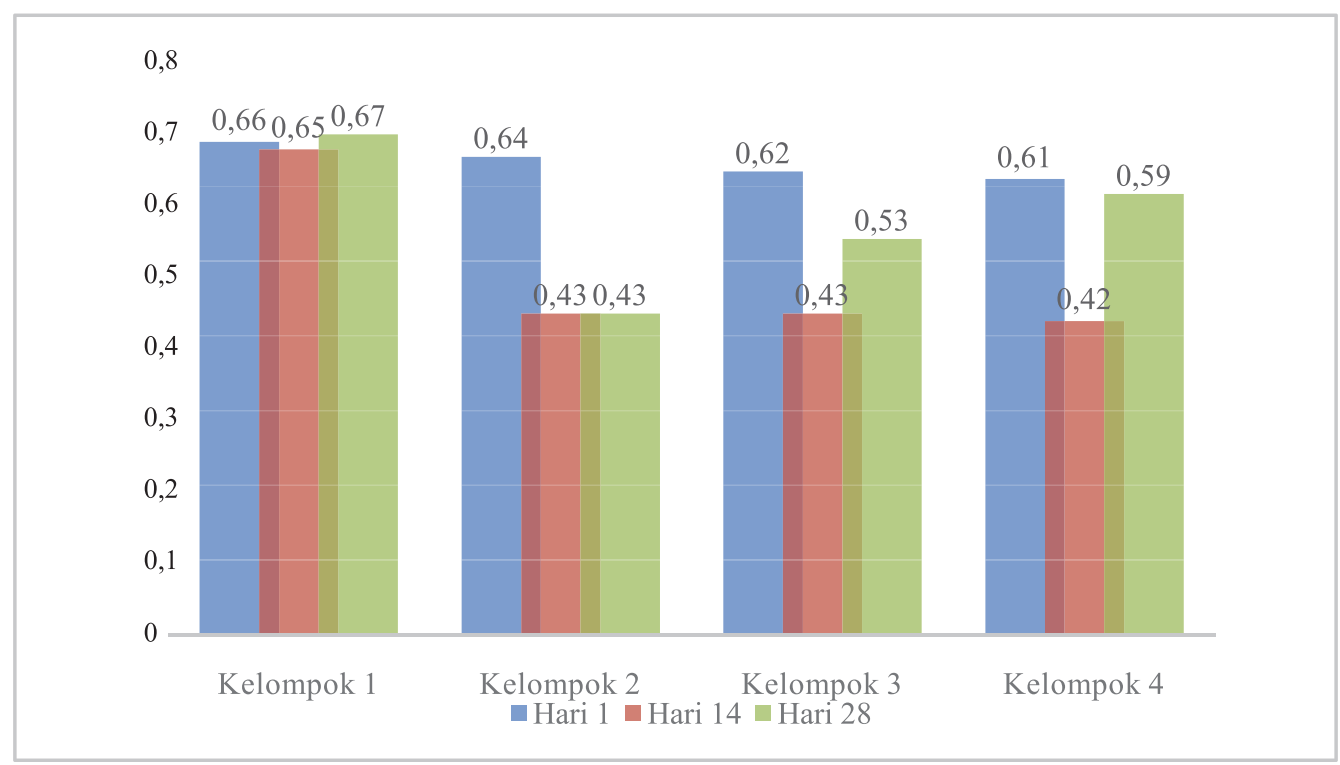

Gambar 1. Diagram Batang Rerata Indeks Rekognisi sebelum Induksi $\mathrm{AlCl}_{3}$ (Hari 1), setelah Induksi $\mathrm{AlCl}_{3}(\mathrm{Hari}$ 14) dan setelah Perlakuan (Hari 28)

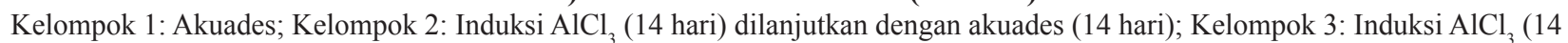
hari) dilanjutkan dengan extra virgin coconut oil (14 hari); Kelompok 4: Induksi $\mathrm{AlCl}_{3}$ (14 hari) dilanjutkan dengan extra virgin olive oil (14 hari). 
Tabel 2. Hasil Uji LSD terhadap Indeks Rekognisi Mencit Swiss Webster (n=24)

\begin{tabular}{llllll}
\hline Perlakuan & n & $\begin{array}{l}\text { Kel 1 } \\
(\mathbf{0 , 6 7})\end{array}$ & $\begin{array}{l}\text { Kel 2 } \\
(\mathbf{0 , 4 3})\end{array}$ & $\begin{array}{l}\text { Kel 3 } \\
(\mathbf{0 , 5 5})\end{array}$ & $\begin{array}{l}\text { Kel 4 } \\
(\mathbf{0 , 6 1 )}\end{array}$ \\
\hline Kelompok 1 & 6 & & $0,000^{* *}$ & $0,000^{* *}$ & $0,004^{* *}$ \\
Kelompok 2 & 6 & & $0,000^{* *}$ & $0,000^{* *}$ \\
Kelompok 3 & 6 & & & $0,015^{*}$ \\
Kelompok 4 & 6 & & & & \\
\hline
\end{tabular}

Kelompok 1: Akuades; Kelompok 2: Induksi $\mathrm{AlCl}_{3}$ (14 hari) dilanjutkan dengan akuades (14 hari); Kelompok 3: Induksi $\mathrm{AlCl}_{3}(14$ hari) dilajutkan dengan extra virgin coconut oil (14 hari); Kelompok 4: Induksi $\mathrm{AlCl}_{3}$ (14 hari) dilanjutkan dengan extra virgin olive oil (14 hari). LSD: Least Significant Difference.

Antara kelompok 3 dengan kelompok 2 didapatkan perbedaan Indeks Rekognisi yang sangat signifikan dan antara kelompok 4 dengan kelompok 2 didapatkan perbedaan Indeks Rekognisi yang sangat signifikan. Hal ini berarti extra virgin coconut oil dan extra virgin olive oil meningkatkan fungsi memori dan belajar mencit setelah diinduksi oleh $\mathrm{AlCl}_{3}$.

Jika dibandingkan dengan kelompok 1, kelompok 3 memiliki perbedaan Indeks Rekognisi yang sangat signifikan dan jika dibandingkan dengan kelompok 4 terdapat perbedaan Indeks Rekognisi yang sangat signifikan. Hal ini berarti extra virgin coconut oil dan extra virgin olive oil meningkatkan fungsi memori dan belajar mencit setelah diinduksi oleh $\mathrm{AlCl}_{3}$, namun hasil peningkatan fungsi memori dan belajar tersebut tidak sebanding dengan kelompok 1.

\section{PEMBAHASAN}

Hasil penelitian ini menunjukkan extra virgin coconut oil berpengaruh dalam meningkatkan fungsi belajar dan memori mencit, dilihat dari Indeks Rekognisi yang lebih tinggi dibandingkan dengan akuades.

Extra virgin coconut oil mengandung medium chain triglycerides (MCT). Medium chain triglycerides merupakan salah satu sumber untuk pembentukan keton. Pada gangguan neurologis seperti pada penyakit Alzheimer, terjadi penurunan glikolisis dan penurunan aktivitas neuron sehingga terjadi penurunan ambilan glukosa oleh otak. Otak akan menggunakan keton sebagai sumber energi yang diperoleh dari oksidasi MCT. ${ }^{12}$ Medium chain triglycerides juga dapat meningkatkan kadar polyunsaturated fatty acid (PUFA) dalam otak sehingga dapat mempertahankan struktur saraf. Selain itu MCT dapat meningkatkan konsentrasi benda keton sebagai energi alternatif untuk otak pada proses penuaan. Komponen fenol dan hormon (sitokinin) yang ditemukan pada kelapa mungkin berperan mencegah agregasi dari amyloid $\beta$ peptidase sehingga menghambat tahap penting dalam patogenesis Alzheimer. Pada penyakit Alzheimer terdapat akumulasi dari amiloid yang merupakan hasil agregasi $\beta$ peptidase. ${ }^{13}$ Penelitian sebelumnya dengan menggunakan 8 ekor anjing dan diberi MCT selama 8 bulan, hasilnya menunjukkan MCT dapat meningkatkan kadar n-3 PUFA di korteks parietal pada anjing lansia. ${ }^{14}$ Penelitian Pan dkk dengan menggunakan anjing yang diberi diet 5,5\% MCT kemudian diuji fungsi kognitifnya, hasilnya menunjukkan bahwa MCT memiliki efek meningkatkan fungsi kognitif dan dapat meningkatkan kadar keton dalam sirkulasi. ${ }^{15}$ Extra virgin olive oil dapat meningkatkan fungsi belajar dan memori mencit yang dilihat dari indeks rekognisi yang lebih besar dibandingkan kelompok yang diinduksi $\mathrm{AlCl}_{3}$. Pada uji statistik dengan menggunakan LSD didapatkan hasil yang sangat signifikan.

Extra virgin olive oil dapat memiliki efek protektif terhadap fungsi kognitif melalui 2 mekanisme yaitu, dengan menekan proses inflamasi dan mengurangi stres oksidatif. ${ }^{16}$ Extra virgin olive oil mengandung polifenol yang dapat meningkatkan aliran darah otak dan memfasilitasi neurogenesis. Polifenol dapat mengurangi kadar reactive oxygen species (ROS), menghambat neuroinflamasi, neurotoksisitas, dan disfungsi neuronal yang disebabkan penyakit demensia. ${ }^{17}$ Extra virgin olive oil juga mengandung asam oleat yang dapat menurunkan 
kadar biomarker inflamasi seperti $C$-reactive protein (CRP) dan TNF. Selain itu extra virgin olive oil juga mengandung fitosterol, vitamin E, komponen fenol yang bersifat antiinflamasi. Untuk mengurangi stres oksidatif extra virgin olive oil mengandung beberapa antioksidan. ${ }^{17}$ Penelitian sebelumnya terhadap aktivitas lokomotor dan neurokognitif pada tikus betina model Alzheimer membuktikan bahwa pemberian antioksidan dapat memperbaiki fungsi kognitif. ${ }^{18}$

Penelitian lainnya menunjukkan hasil berupa extra virgin olive oil memiliki efek yang menguntungkan pada defisit belajar dan memori yang disebabkan oleh penuaan atau penyakit. ${ }^{10}$ Studi lain setelah 8 minggu dilakukan uji moris water maze dan disimpulkan ekstrak polifenol dari buah kenari dapat meningkatkan fungsi belajar dan memori mencit. ${ }^{19}$ Studi lainnya juga menunjukkan bahwa kelompok yang diberi intervensi MedDiet yang ditambahkan dengan extra virgin olive oil memiliki fungsi kognitif yang lebih baik dibandingkan dengan kelompok kontrol negatif. ${ }^{17}$

Extra virgin olive oil jika dibandingkan dengan extra virgin coconut oil didapatkan hasil indeks rekognisi yang berbeda siginifikan. Hal tersebut berarti terdapat perbedaan peningkatan fungsi belajar memori mencit antara kedua bahan uji tersebut. Extra virgin olive oil lebih baik dibandingkan dengan extra virgin coconut oil dalam meningkatkan fungsi belajar dan memori mencit dilihat dari IR pada kelompok mencit yang diberi extra virgin olive oil lebih tinggi dibandingkan kelompok mencit yang diberikan extra virgin coconut oil.

Extra virgin olive oil lebih baik bila dibandingkan dengan extra virgin coconut oil kemungkinan karena extra virgin olive oil mengandung polifenol yang dapat bekerja sebagai penghambat neuroinflamasi, neurotoksisitas, dan disfungsi neuron, sedangkan coconut oil mengandung hanya MCT sebagai kandungan utama yang berperan sebagai sumber energi utama bila terjadi kerusakan saraf.

Keterbatasan penelitian ini antara lain tidak dilakukan uji kandungan bahan extra virgin olive oil dan extra virgin coconut oil yang digunakan, durasi induksi $\mathrm{AlCl}_{3}$ hanya menggunakan durasi minimal yaitu 14 hari, serta tidak adanya kelompok kontrol positif.

\section{KESIMPULAN}

Hasil penelitian ini menunjukkan bahwa extra virgin coconut oil dan extra virgin olive oil berpotensi sebagai suplemen untuk meningkatkan fungsi memori dan belajar, khususnya penderita demensia. Namun penelitian ini masih terbatas pada hewan coba sehingga perlu penelitian lanjutan untuk membuktikan efeknya pada manusia, termasuk uji dosis dan efek samping.

\section{DAFTAR PUSTAKA}

1. Redjeki S. Kontribusi serebelum dan ganglia basalis pada seluruh pengendalian motorik. Dalam: Tanzil A, editor. Guyton and Hall buku ajar fisiologi kedokteran. Singapore: Elsevier; 2016. h. 684.

2. Cook AM, Polgar JM. Assistive technologies: principles and practice. Edisi ke-4. Missouri: Elsevier Mosby; 2015.

3. Sherwood L, editor. Fundamental of human physiology. Edisi ke-4. Belmont: Cengange Learning; 2012.

4. Chouliaaras L, Topiwala A, Cristescu T, Ebmeier KP. Establishing the cause of memory loss in older people. Practitioner. 2015;259(1778):15-9, 2.

5. Canada Society Alzheimer. Young onset dementia; 2015.

6. National Center for Learning Disabilities. The state of learning disabilities: facts, trends and emerging issues; 2014.

7. WHO. Fact sheets dementia 7; 2016.

8. Nampoothiri M, John J, Kumar N, Mudgal J, Nampurath GK, Chamallamudi MR. Modulatory role of simvastatin against aluminium chlorideinduced behavioural and biochemical changes in rats. Behavioural Neurology [serial online]. 2015 [diunduh 20 Januari 2016];210169. Tersedia dari: Hindawi.

9. Doty L. Coconut oil for Alzheimer's disease. Clin Pract. 2012;1(2):12-7.

10. Farr SA, Price TO, Dominguez LJ, Motisi A, Saiano F, Niehoff ML, dkk. Extra virgin olive oil improves learning and memory in SAMP8 mice. J Alzheimer's Dis. 2012;28(1):81-92.

11. Leger M, Quiedeville A, Bouet V, Haelewyn B, Boulouard M, Schumann-bard P, dkk. Object recognition test in mice. Nat Protoc. 2013;8(12):2531-7.

12. Cunnane SC, Courchesne-Loye A, Vandenberghe 
C, St-Pierre V, Fortier M, Hennebelle M, dkk. Can ketones help rescue brain fuel supply in later life? implications for cognitive health during aging and the treatment of Alzheimer's disease. Front Mol Neurosci. 2016;9(53):1-21.

13. Fernando WMADB, Martins IJ, Goozee KG, Brennan CS, Jayasena V, Martins RN. The role of dietary coconut for the prevention and treatment of Alzheimer's disease: potensial mechanisms of action. Br J Nutr. 2015;114(1):1-14.

14. Taha AY, Henderson ST, Burnham WM. Dietary enrichment with medium chain triglycerides (AC1203) elevates polyunsaturated fatty acids in the parietal cortex of aged dogs: implications for treating age-related cognitive decline. Neurochem Res. 2009;34(9):1619-25.

15. Pan Y, Larson B, Araujo JA, Lau W, De-Ivera C, Santana R, dkk. Dietary supplementation with mediumchain TAG has long-lasting cognition-enhancing effects in aged dogs. Br J Nutr. 2010;103(12):1746-54.

16. Martinez-Lapiscina EH, Clavero P, Toledo E, Julian BS, Sanchez-Tainta A, Corella D, dkk. Virgin olive oil suplementation and long-term cognition: the predimed navarra randomized, trial. J Nutr Health Aging. 2013;17(6):544-52.

17. Vauzour D. Dietary polyphenols as modulators of brain functions: biological actions and molecular mechanisms underpinning their beneficial effects. Oxid Med Cell Longev. 2012;2012(914273):4-6.

18. Fasrini UU, Susanti R, Lipoeto NI. Efek gambir (uncaria gambir/hunter roxb) terhadap aktivitas lokomotor dan neurokognitif pada tikus betina model Alzheimer. Neurona. 2017;35(1):17-23.

19. Shi D, Chen C, Zhao S, Ge F, Liu D, Song H. Effects of walnut polyphenol on learning and memory functions in hypercholesterolemia mice. J Food Nutr Res. 2014;2(8):450-6. 